\title{
An Exploratory Study of Accounting and Reporting Practice for Waqf Among State Islamic Religious Councils in Malaysia
}

\author{
NORI YANI ABU TALIB*, RADZIAH ABDUL LATIFF, AINI AMAN \& MOHD RIZAL PALIL1
}

\begin{abstract}
Nowadays, Muslims has been exposed to the increasing number of waqf practice and the importance of waqf to the society due to the huge benefits in the socio-economic development and assist the poor and those in need. However, there is a lack of accounting system and systematic management of waqf assets and the absence of written procedures of recording financial transactions of waqf assets. The purpose of this research is to identify the range of differences of waqf accounting practice in details and discover the rationale behind the diverse of accounting and reporting practices for waqf. It examines accounting and reporting practices in terms of recognition, measurement and disclosure in eleven selected state waqf institutions. It provides an insightful meaning of the issues and challenges on how accounting is practice in these State Islamic Religious Councils (SIRCs). From the analysis conducted, it is found that the financial accounting and reporting related to waqf in SIRCs differs in terms of the guideline used, the recognition and measurement (valuation of waqf asset) as well as the disclosure and reporting practice of waqf. The variations of accounting and reporting practices in these waqf institutions portray the dynamism of waqf accounting and reporting among SIRCs in Malaysia. The reason for the variation in accounting practice is attributed to the nature of SIRCs governance where each SIRC is headed by its ruler (Sultan) as the ultimate authority in Islam and the fatwa councils' decision. The decision of the Board members with regard to the management and administration of waqf may differ in each states.
\end{abstract}

Keywords: accounting, Islamic Religious Council, waqf, waqf accounting and reporting, waqf management

Waqf is an Arabic term means to hold, confinement or prohibition (Kahf 1998). Waqf is referring to non-perishable property whose benefits and usufruct can be extracted without consuming the property itself. It is an honest gift in the form of private possession to the state or person of authority for the benefits of all as long as the wealth is used in accordance with the Islamic requirements (Masruki \& Shafii 2013). Waqf properties currently being managed by the state through its state Islamic religious councils in Malaysia. Each states is empowered to manage its own

\footnotetext{
${ }^{1}$ Nori Yani Abu Talib*(Corresponding author), Ph.D. candidate at Faculty of Economic and Management, Universiti Kebangsaan Malaysia, 43600 BANGI, Selangor, Malaysia, email: noriyaniat@gmail.comi Radziah Abdul Latiff, Ph.D., senior lecturer at Faculty of Economic and Management, Universiti Kebangsaan Malaysia, 43600 BANGI, Selangor, Malaysia, email: radziah@ukm.edu.my; Aini Aman, Ph.D., assoc. prof. at Faculty of Economic and Management, Universiti Kebangsaan Malaysia, 43600 BANGI, Selangor, Malaysia, email: aini@ukm.edu.my; Mohd Rizal Palil, Ph.D., assoc. prof. at Faculty of Economic and Management, Universiti Kebangsaan Malaysia, 43600 BANGI, Selangor, Malaysia, email: mr_palil@ukm.edu.my.
} 
state waqf including land, buildings and cash donated by the donors of waqf. However, the challenges in managing the waqf is the diversification of the waqf practices which has been emphasised by many scholars which may hinder the standardisation of the waqf practices in Malaysia. Past studies has emphasised on the lack of proper accounting record for waqf institution in Malaysia (Abdul Rahman et . al. 1999; Siti Rokyah 2005; Ihsan 2007; Ihsan \&Adnan 2009; Ihsan \& Ibrahim 2011). There is a lack of accounting system and systematic management of waqf assets and the absence of written procedures of recording financial transactions of waqf assets (Abdul Rahman et al 1999). Mustafa (2007) found that most state waqf institutions had no up-to-date audited financial statements. Terengganu SIRC also faces the same problem on the unsystematic documentations which lead to an obsolete record and unsystematic waqf property data.

The lack of proper accounting record has been associated with the absence of a standard for waqf accounting and reporting (Masruki \& Shafii 2013). Thus, recent scholars has emphasised on the importance of having a standard for waqf administration in order to resolve the issue of accountability and transparency of the waqf institutions in Malaysia (Adnan et al. 2007; Hamdan et.al, 2013; Dahlan et.al, 2014; Ihsan et al. 2016). The growing number of waqf nowadays, which can be considered as a huge amount of waqf assets that can be developed and contribute to the socioeconomic development, has led to the importance of having a good accounting and reporting standards for waqf. There is a growing awareness concerning the accountability of the trustee in managing waqf and being an institution that delivers social services to the community, the demonstration of accountability to various stakeholders is required (Ihsan et al. 2016). An effort has been done by few related parties to develop a standard for waqf for all SIRCs in Malaysia. This can be seen from the recent effort by the Accountant's general department of Malaysia with the collaboration of few groups of universities' researchers in Malaysia to set up a standard in order to facilitate the management and administration of waqf assets. Up to date, there is a call towards the standardised waqf accounting and reporting. However, there is lack of study explores the similarities and differences that exist among the State Islamic Religious Councils in Malaysia pertaining to the treatment, recognition of waqf asset, measurement and valuation of the waqf lands and buildings as well as the disclosure and reporting practices in these waqf institutions. Perhaps, the study may be useful and may provide an insight on how these differences can be resolved and achieving the standardisation of waqf accounting and reporting among all SIRCs in Malaysia.

This paper purposes to understand and examine the diversity of waqf accounting and reporting practices in waqf institutions in Malaysia namely State Islamic Religious Councils (SIRCs). The research questions focus on (1) how does waqf transactions of SIRCs in Malaysia being accounted and reported? (2) Why waqf accounting practices in SIRCs differs in terms of recognition, measurement or valuation as well as disclosure. Using a case study of 11 waqf institutions in Malaysia, this paper provides empirical evidence of similarities and differences in the practices of waqf accounting and reporting among SIRCs in Malaysia.

\section{Waqf Accounting and Reporting Issues}

The issues discussed below are related to the waqf accounting and reporting in the States Islamic Religious Councils in Malaysia which become the factors leading to the call for standardization of accounting and reporting for all waqf institutions in Malaysia. 


\section{Diversification of Waqf Accounting and Reporting Practices}

In Malaysia, any matters related to waqf are solely controlled and administered by SIRC in accordance to The Federal Constitution's Ninth Schedule, List II (State List). The jurisdiction of SIRC as the sole trustee of waqf land has clearly been embedded in each respective state enactment. All waqf land, whether movable or immovable could only be administered and managed by the council (Ismail et. al, 2015). Thus, recording and reporting for waqf in Malaysia has been inconsistent. It has been noted that different waqf institutions has its own accounting practice (Masruki \& Shafii 2013). It was found that there are different approaches used by the councils in presenting their financial report (Md. Zain \& Abdul Rahman 2006). In Malaysia, the discord in the administration of waqf may be stemmed from the dissimilarity of management in each SIRCs. The differences in the waqf administration has led to the disharmony of accounting and reporting practice including waqf. This may be influenced by the lack of central management and authority by the Federal government as well as the diverse Shariah opinions held by the each SIRCs. The recording and reporting for waqf differ in terms of the reference or guideline used in accounting for waqf, the recognition of the waqf asset, the valuation of the waqf asset, as well as the way SIRCs disclose and report their financial activities related to waqf. The diversity of accounting practices among SIRCs has become the main reason of different treatment in valuing waqf asset like land and building (Abdul Rahman et. al. 1999 \& Hamdan et. al. 2013). Besides, waqf institutions are governed by different laws and regulations, the nature of the administration of these institutions may differ from one state to another and may lead to administrative problems (Hassan 2008).

The Lack of Central Management and Authority at Federal level

The central management and authority at Federal level is very essential to ensure the management and administration of waqf properties is in order, systematic and effective (Siti Rokyah 2005; Ihsan 2007). Masruki \& Shafii (2013) suggest that JAWHAR uses reporting as a tool to measure the performance of waqf institutions and set up guidelines to be enforced and monitored at federal level. Nonetheless, JAWHAR currently plays its role as an advisor but has no enforcement power. The lack of central management and authority may be a cause of the discord and disharmony of accounting and reporting for waqf in SIRCs in Malaysia. According to Masruki \& Shafii (2013), the lack of proper waqf recording and management of waqf asset is due to the lack of coordination of waqf institutions by the federal authority in Malaysia. Recognising the potential and role in the economic development of the waqf, the Government of Malaysia has established JAWHAR in 2004 to strengthen the waqf governance across the country, while Yayasan Waqf Malaysia (YWM) was established in 2008 acting as the lead agency in developing the waqf property. Both of these agencies have undertaken numerous initiatives including activities research, publication, coordination and development of waqf properties in throughout the country (Hasan et. al. 2015).

The SIRC is furnished with the authority to appoint any individual or a board to act as its representative to execute the administrative duties of the trusteeship of the waqf property. Under the provisions of 3 (2) of the Federal Constitution states that the king is as the head of the religious of the states that have the King and Yang Di Pertuan Agong as head of the states that do not have Sultan or King (Mat Rani \& Aziz 2010). The administration of Islamic legal matters in Malaysia is upheld by the Federal Constitution. The Civil Law that is enacted at the state level should not contradict the Federal Constitution (Federal Constitution, Article 75). Though, any matters involving to the Administrative Affairs of Islam or Islamic law are placed under the jurisdiction of 
the State government. Only the Federal Territory is exempted from this ruling. The establishment of the SIRC is an adviser to the Sultan, in matters relating to formulation of policies on Islamic affairs. The policy implementation is carried out by either the SIRC itself or Islamic Department of each state. These provisions provide the consequences in terms of the management of each state to formulate policies and activities at their own discretion include matters concerning to the waqf. This situation opens a space to the existence of management problems that vary from state to state for example the difference types of waqf being managed as well as the variation in terms of the waqf asset valuation period, recording and reporting treatments for waqf and so on.

Besides, the administration of affairs related to Islamic religion is governed separately in every state and is not standardised whether in legislation, management and implementation among the states in Malaysia (Sayin et. al. 2006; Mat Rani \& Aziz 2010). Ismail et. al.(2015) suggest the role of Department of Awqaf, Zakat and Hajj (JAWHAR) to be strengthened to help, facilitate and complement the efforts SIRC has taken in improving the efficiency and effectiveness of waqf administration, management and development. Masruki and Shafii (2013) recommended that JAWHAR uses reporting as a tool to measure the performance of waqf institutions and set up guidelines to be enforced and monitored at federal level. Mohd Saharudin Shakrani et.al (2003) also suggest that there is a need to create a board at federal level which manages and report every information received from each states regarding waqf. This board also makes analysis about the economic development of the Muslim community as a whole and investment opportunities towards waqf properties that has potential to increase in value. This board also supervise matters pertaining to state waqf.

\section{Diverse Shariah Opinion}

Each states may have diverse Shariah views concerning waqf management and the need for a standardised waqf accounting and reporting. Every decision or ruling relating to Islam is seen as the sole authority of the states. It is placed under a body known as the National Council for Fatwa Committee of Islamic Religious Affairs Malaysia Uawatankuasa Fatwa Majlis Kebangsaan Bagi Hal Ehwal Agama Islam Malaysia). At the state level, institutional fatwa is a legal entity other than the State Islamic Religious Council, State Islamic Religious Department, and Shariah Court granted recognition by each state's Shariah law (Dahlan et. al. 2014). A fatwa means a decision officially given by a Mufti or a Shariah State Committee published in the State Official Gazette. Once a fatwa is published in this fashion, it becomes binding upon all Muslims residing in the state (Buang 2002). The sources of waqf is derived from the Al-Quran, and Assunnah (hadith) as the main sources of the Shariah, the secondary source is derived from the human reasoning and interpretation (ijtihad) by the Islamic jurist which is known as Ijma' (the consensus among the Islamic scholars) and Qiyas (the opinion of individual jurist) (Yaacob 2013). Thus, the jurisprudence regarding waqf is based on Ijtihad. Malaysia basically takes after "mazhab" Shafie in the decision regarding waqf. However, certain SIRCs find the decision under the Shafie is excessively unbending hence restrain the improvement of waqf area. Accordingly, these religious councils adopt the rulings and the decisions from other "mazhabs, for example, Hanafi, Maliki and Hambali as they see fit for various circumstances. Thus, the diversification of waqf management and accounting practices among SIRCs might be influenced by the differences in the Shariah opinion held in each state.

The waqf legal problem of inconsistency between states has created the difference in the understanding, interpretation, procedures of fatwas decision and ruling. This stems from its waqfas other religious matters are under the jurisdiction of the state (Federal Constitution the Ninth Schedule list 2 (1) and no enactment specifically related to the management and the administration of waqf in the states except Selangor (Wakaf Enactment (Selangor), 15/2015), Negeri Sembilan

https://doi.org/10.24035/ijit.13.2018.009 
(Wakaf Enactment Act 2005), Malacca (Wakaf Enactment Act 2005) and Perak (Wakaf Enacmemnt Act 2015). Thus, the enactment and Act on waqf seems narrow and volatile. The critical issues related to waqf actually stem from the government policies and the Malaysian Constitution itself which has been a part of religious institution management of each states (Mohamad Zaim et. al. 2015).

\section{Different Legal Form of SIRC in Malaysia}

Waqf institutions in Malaysia consist of different legal form of organisation. Some of the waqf institutions operates as an incorporated body of the SIRCs for example Perbadanan Wakaf Selangor (PWS), an incorporated body of Selangor SIRC. Meanwhile, the PWS has also established a subsidiary company namely Urus Maju Ehsan Sdn Bhd. The PWS and the subsidiary company may have different accounting and reporting framework for waqf from its parent (SIRC) due to the different guideline used in the preparation of accounts for waqf. Instead of following the parent, the PWS and subsidiary company may have different set of waqf account as the subsidiary company is subjected to relevant Malaysian Financial Reporting Standard (MFRS). This situation is common with the SIRC in Negeri Sembilan, which has established an incorporated private company namely Perbadanan Wakaf Negeri Sembilan Sdn Bhd (PWNS). The PWNS was established in 2004 in order to manage all waqf in Negeri Sembilan and accounts will be consolidated with Negeri Sembilan SIRC (MAINS) at the end of the year.

Some of waqf institutions operate as a separate unit in SIRC for instance waqf institution in Pahang which is known as Unit Saham Wakaf, is a separate unit under the SIRC of Pahang. This unit will report its financial statement to the SIRC of Pahang to be consolidated with its SIRC account. The unit needs to disclose all activities and transactions related to waqf by preparing the report to their Head Office (Pahang SIRC), and related account (for examples collection of cash waqf as revenue) will be joined together in the finance department in Pahang SIRC. Whereas, there are waqf organisations act as a department in the SIRCs normally the finance department. These finance departments will record all the transactions related to waqf for instance the collection of rental, cash waqf through the SIRC counter, special waqf administration. At the end of the month, the departments will prepare the report for each waqf account either separate reporting or combine reporting. The separate reporting means the waqf has its own accounts for example, waqf of a mosque, school or shop lot which have its own bank account and cash flow statements. The SIRCs may have numbers of different waqf account, and present separately. The combine reporting is when the SIRCs combine the waqf amount balance in the SIRC financial statements.

\section{The Need for Standardisation of Waqf Accounting and Reporting}

The revival of waqf institutions creates the need to establish good accounting system for these institutions. The absence of guidelines or standards on accounting for waqf generates the interest of few researchers to propose the relevance of waqf accounting so that transparency and accountability of waqf institutions could be assured. Accounting for waqf is a useful means to discharge mutawalli's (trustee) accountability in waqf administration and management (Masruki \& Shafii 2013). Besides, accounting and reporting for waqf is very crucial to enhance the transparency and accountability of the waqf institutions due to the reason that waqf deals with the charitable assets which meant for public. Up to date, there is an absence of specific standard or guideline on accounting and reporting for waqf and no detailed information about the waqf assets being recorded. The different in accounting and reporting for waqf may create the issue of lack of 
transparency, accountability, efficiency and comparability as highlighted by previous scholars that suggested on the need for a standard of waqf accounting and reporting (Abdul Rahim et. al. 1999; Siti Rokyah 2005; Hisham 2006; Ihsan 2007; Mohd Nasir 2009; Ihsan \& Adnan 2009; Ihsan \& Ibrahim 2011; Daud et. al. 2012; Masruki \& Shafii 2013).

Many scholars highlight on the need for a more reform and uniformity of waqf management and administration in Malaysia especially in the legal framework and financial aspects which include accounting and reporting practices. It is suggested that a standard law in relation to waqf be enacted and be adopted by each state so that there were uniformity in the law with regard to power and authority for the development of waqf property. According to Isa et.al (2011), up to this point, it is realised that waqf properties are under supervision of each State religious council. This will create a gap in waqf administration. To conquer this issue, perhaps there is a need to set up a waqf administration net that is effective for all states in Malaysia. The technique "Benchmarking" must be executed by the state waqf administration in different states all through the nation. It additionally can give more exposure and improve the quality of waqf administration.

Prior studies has indicated the importance of standard for waqf and provide the proposal for a good standard for waqf. However, here are lack of study that examines intensely and comprehensively on the similarities and differences exist in the SIRCs with regard to the accounting and reporting for waqf. Perhaps, it may be essential to initially explore the waqf accounting practices in all SIRCs in Malaysia before developing a standard that may be used by all SIRCs to achieve the standardisation.

\section{The Development of State Islamic Religious Councils in Malaysia}

In the early day, Muslims donated their waqf property to the village principle (penghulu) as their waqf trustee. Syed Abdul Kadir (2011) states that the waqf was managed by the community leaders like kadis, imams, bilals and penghulus in the early days. However, the records were only based on the verbal transactions. The problem happened when the penghulu died and other person took charge of the affairs, the descendants of the deceased "penghulu", sometimes ignore the declaration of the waqf property and used it as their own property (Yaacob 2013). Unfortunately, there are no legitimate written documents with respect to the primary establishment of waqf in Malaysia before the nineteenth century. The earliest written records that accessible were the waqf of Masjid Capitan Kling in 1801, and the waqf by a member from the Acheh royalty in Penang (Nasution 2002).

Nowadays, the development of productive waqf can generate income and increase the value of waqf assets. Waqf has become the model of Islamic economic development. Malaysia possessed a lot of waqf assets especially land and if being developed properly it may contribute positively to the development of Muslim. Isa et. al. (2011) indicates that there is an increase in total waqf land in Malaysia by the Muslims from time to time. In any cases, the issue in question is the amount of the waqf property that can completely advantage the local Muslim community (Arkib 2009). In 2014, the total estimated amount of waqf land has reached RM 1,177,084,450.59 as reported by JAWHAR. On the off chance that these waqf land are productively overseen and developed, they could yield billions of income to the Muslim community. Moreover, the huge value of waqf assets indicates the significance of waqf as a means for Islamic economic development and the need of proper waqf accounting and reporting by waqf institutions in Malaysia.

The SIRCs (Majlis Agama Islam Negeri) are religious institutions in this country that play important roles in developing and managing all waqf assets (Mat Rani and Aziz 2010). The purpose of the appointment of the council as the sole trustee of the waqf estate is to ensure that the waqf managed and well-administered efficient in generating substantial revenue for the welfare of the 
people. There are 14 State Islamic Religious Councils in Malaysia with each targeted of making the administration of waqf efficient and effective for the benefits of the society. Although waqf has long been undertaken by the Muslims in Malaysia, the institutionalised management of waqf only came about in 1952 when express powers to manage matters relating to waqf was granted to the State Islamic Religious Councils (Mohamad et al. 2012).The administration of waqf is under the power of the State Islamic Religious Councils which having their own particular offices and units do the management of the waqf property for the advantages of the beneficiaries named in the waqf. Albeit the increasing emphasis on the standardisation of waqf accounting and reporting in SIRCs, it seems that there are certain constraints and obstacles existed in these Malaysian waqf institutions in order to adopt a similar accounting and reporting framework. Due to the nature of waqf administration is regulated through various states law or enactment, where each SIRC is directly under the supremacy of each states' ruler (Sultan). Every decision made to the SIRC is subjected to their Board and Fatwa committees' approval. For example, the investment of waqf land also adheres to the roles play by the National Fatwa Committees. Any issues involved in the investment plan project and waqf affairs shall be referred to the respected fatwa committees. Thus, this paper explores the waqf accounting and reporting practices in eleven SIRCs in Malaysia in order to provide better insight on the constraints and obstacles existed in each states waqf institution.

\section{Research Method}

This paper carries out the positivist comparative case studies inspired by Yin (1994; 2015), Eisenhardt (1989), Miles and Huberman (1994; 2014) and few other scholars who are strong proponents of and have wide practice in the research approach. This exploratory case study based on multiple case study is aimed at defining questions in order to provide deeper understanding on the current accounting and reporting in waqf institutions in Malaysia. Yin (1994) explains that the case study research strategy is most likely to be appropriate for "how" and "why" research questions. As for this paper, the research questions are how does waqf institutions record and report transactions related to waqf and why the accounting and reporting for waqf do differ. Out of the fourteen SIRCs in Malaysia, only eleven SIRCs were selected based on the convenience sampling. Those selected SIRCs are situated in Peninsular of Malaysia excluding Sabah and Sarawak and one SIRC rejected to be interviewed. The finance managers or accountants who are directly involved in accounting and reporting activities including on waqf from each SIRC were interviewed to obtain the information and answer the research questions developed in this study. Besides, the researcher also collect data in the forms of documents like the related manual guideline, financial reports and statements of the SIRCs in order to get the understanding on current waqf accounting and reporting practice in SIRCs. In order to ensure the reliability and validity of the analysis and findings of the questionnaire survey, a semi-structured interview by face to face was chosen. The interview transcripts were developed and emailed to the participants again to verify the information and data gathered from the interview. The adoption of multiple data sources is an attempt to ensure the reliability and the validity of the interview findings. Part of the financial statements and reporting were collected by the researcher for the purpose of validating the data.

The data analysis also involves a process known as coding. Conceptualising, reducing, elaborating and relating are referred to coding (Miles and Huberman 1994 \& Strauss and Corbin 2008). In qualitative research, coding represents another tool to support researchers during early analysis. The coding scheme is used to organize segments of similar or related text for ease in interpretation and to search for confirming/disconfirming evidence of these interpretations. Coding itself can be performed with the help of a specialised computer program which makes the sorting,

https://doi.org/10.24035/ijit.13.2018.009 
cutting, and pasting operations more efficient (Weitzman 2000). The researcher also uses the ATLAS.Ti software to facilitate the process of coding and analysing the data.

\section{Findings \& Analysis}

\section{Accounting and Reporting of Waqf}

Thematic analysis (Braun \& Clarke 2006) of the response demonstrates that the existing treatment for accounting and reporting for waqf is inconsistent. The inconsistency can be observed in terms of different types of waqf management, the recognition of waqf asset (cash, land and building), measurement or valuation of the waqf asset as well as reporting and presentation. For waqf institutions like SIRCs, there are two types of waqf available which is general waqf (wakaf am) and specific waqf (wakaf khas). However, not all SIRCs have specific waqf and study found all of waqf institutions has the general waqf (wakaf am) but not all waqf institutions have the specific waqf. This is because the complication in managing the specific waqf. The following statements provide the evidences on why this situation occurs in SIRCs.

"So far, our waqf institution is not yet towards the specific waqf (wakaf khas). Perhaps, we are looking into few considerations regarding the waqf asset that is not suitable for the purpose of specific waqf. For example, those who aims to donate their land but their intention for the specific purpose is not suitable to be implemented. Let say, this land is donated for the mosque construction, while, there is an existing mosque built near the waqf land. This is a reason that I understood why our organisation is more focusing on general waqf rather than specific waqf" (P18)

"We now do not take special waqf as it is quite complicated and involves a lot of charitable recipients from generation to generation. Rather difficult." (P13)

The management of specific waqf is not suitable for the specific requirement made by the donor and the impossibility of the requirement to be made. Besides, the difficulty of the specific waqf management may be the nature of the specific waqf which sometimes the SIRC cannot fulfil the requirement made by the donor due to the certain circumstances.

With respect to the capitalisation of asset, according to the Enactment Act of the SIRC, the SIRC play its role as a trustee of the waqf asset and not as the owner. Thus, this restriction prevents the SIRC to capitalise the waqf asset and present it in the financial statement.

"SIRC is not the owner of the asset and SIRC is just a trust holder (trustee) in Section 61 , and until now we didn't record the asset of waqf, we only proclaim it in Section 68. In terms of accounting asset is only recorded when we own the asset". (P4)

"We will only make valuation to the land that will be developed. The value will be recognised as an asset. But there is also assets that we do not capitalise them but we put as a token rm10. We recognise as asset if we get the title transfer". (P13)

Recognition of Waqf Asset 
Some of the SIRCs present their waqf asset with the nominal value. Meanwhile others do not. The reason behind the recognition of waqf asset with nominal value is actually to indicate the existence of waqf asset like building and land. However, the actual value is not identified and unknown. This is because the SIRCs did not make valuation of asset. And if the valuation is made for few SIRCs, the revaluation is not done yearly. This may incur high cost for SIRCs to make revaluation and the SIRC cannot bear the cost of the assets. Limited funding is also among the main causes that hinders the development of waqf land (Mohamad et. al. 2012).

"We put the value of RM1 so that we can see those waqf land." (P1)

"Only RM1.00 to simply describe the waqf land is there" (P9)

"Sometimes in waqf building is a dilapidated house but partially rated as RM1 to indicate the presence of the endowment assets." (P20)

Normally, the SIRC will only list their waqf asset like land and building without value or with the value at the time of submission.

"If there is value given together with asset of waqf, we will put the figure together in the Balance Sheet. If given to us without value, we will take it out to notes to account. As we have few categories for example Mosque, small Musalla, school site, and general waqf. If a house we put it under general waqf (wakaf am)." (P2)

Some of the SIRCs did not recognise the waqf assets at the nominal value because the participants view that the value of RM1.00 does not reflect the actual value of the waqf assets. Thus, there is no point for the accountants to recognise the waqf asset at the nominal value as indicated by other participants of different SIRC.

In term of recognition of cash waqf, there are two different treatment of provided by these SIRCs. Firstly, waqf assets in terms of cash of SIRCs is recognised as Amanah Account which is considered as the liabilities of SIRC. This cash waqf is recognised as a liability as the SIRCs are holding a trust in terms of cash. This money will be used to distribute to the beneficiaries and etc. The SIRCs consider themselves as having responsibilities that must be implemented.

"Yes, as we regarded waqf as Amanah Account. Before 2003, we used to hold it as in Profit and Loss Account, but when we have looked and discussed again. We change the treatment of waqf to Amanah Account, and Fatwa also decided so. Thus, we made the changes all waqf asset as Amanah. No more P\&L." (P2)

SIRCs that collect cash waqf and recognise it as SIRC revenue and present in the Profit and Loss Account. However, the waqf account (revenue) of waqf unit will not be included in the accounts of those SIRC. This waqf has its own bank account.

"Waqf account is not included in the accounts of parents. He's got his own bank. We have a waqf trust fund Tabung Amanah Saham Wakaf and yet the Tabung Dana Wakaf. For this money will not mix up with the money of zakat and baitulmal. Indeed separately." (P8) 
"the treatment for cash waqf is crediting the sales revenue. The collection will be accounted as revenue. So far, we have some collection but not so many as we have just started the system of Dana Wakaf..." (P6)

Thus, the concept of cash waqf is treated as a liability is totally different from the concept of cash waqf as a revenue. If the cash waqf is recognised as an amanah account, the movement of the money can be revised and the SIRC is liable to hold the money for certain waqf project. However, if the cash waqf is recognised as sales revenue, the money will be set off and SIRCs will lose the money.

\section{Measurement or Valuation of Waqf Asset}

The revaluation of asset was done for instance Kelantan, which value their waqf asset one in five years. Meanwhile, Terengganu and Johor decide to make valuation of waqf asset when they feel necessary to do so and some do it when the waqf asset is ready to be developed. Hence, five of the SIRCs did not make any revaluation. From the analysis conducted, most of the SIRCs do not value their waqf assets like land and building. The waqf assets are not capitalised, the value and the land area is unknown. However, when the asset is developed, some SIRCs do value the asset and present it in the SIRC account. For the purpose of capitalisation, SIRC must obtain the title of the land before the SIRC can report their waqf asset in the financial statement.

"Yes, we will value the waqf asset. Examples, at first, we enter the token RM10, the land that we made construction. Let say, the cost of construction was RM 3 million excluding the value of RM 10. Until the building is completed, I will send it to Jabatan Penilaian Hartanah Malaysia next year to make a revaluation. Next year, then I can report how much the cost of land, cost of the building." (P13)

"If we follow the audit, we revaluate once in 5 years unless the land is for sale. For reporting purposes, we will value the asset for 5 years." (P5)

"Like I said, until now, we are unclear as to determine whether the value of the property donated, whether current value or no value which as a token of RM1.00 in the financial statements. For example of the special waqf, although MAIK administer, MAIK does not have the power except for the will. Because that asset is not our wealth either." (P5)

The participants indicated different approaches of waqf asset valuation treatment. The value of the waqf assets also differs as some SIRCs value as nominal value of RM1.00 or RM10 upon existence and some do not value at all. The challenges of the SIRC in the process of valuation is the uncertainty in recording the waqf asset whether recognising it at market value or nominal value. The study of Mustaffha and Firdaus Zainal (2016) reported earlier that SIRCs still have improper accounting records regarding waqf assets. They have not properly recorded comprehensive assets listings, their current value and waqf accounts.

Disclosure and Presentation of Waqf

https://doi.org/10.24035/ijit.13.2018.009 
Majority of the SIRCs provide the listing of all waqf assets with and without value depending on the SIRC's requirement. The disclosure of the waqf asset is not revealed in the financial reporting. However, the presentation of waqf asset only be made for waqf asset that is owned by the SIRCs through purchase. Besides, there are few SIRCs prepare the assets listing in the notes to account and some do not. Thus, it was found that the format of waqf reporting varies among SIRCs. The SIRCs in Malaysia also have different ways of disclosing and reporting their waqf assets. For example, the SIRC of Terengganu, Kelantan and Pahang, do not separate the waqf related activities or transactions from the account of the SIRCs. This means at the end of year, the waqf assets and revenues, liabilities and expenses related to waqf are added to the account of the SIRCs. Prior study indicate that majority of SIRC did not separate its waqf account (Ihsan \& Ibrahim 2011). Whereas, few SIRCs or waqf units has its own financial reporting specifically for waqf which are later consolidated in the SIRCs reporting which is known as Kumpulan Wang Wakaf like SIRC of Selangor, Johor, Wilayah Persekutuan and Negeri Sembilan.

"In this state council, we have 5 different funds that we maintain which are the collection of zakat fund (Kumpulan Wang Wakaf), group of wakaf fund (Kumpulan Wang Wakaf), general resource group (Kumpulan Sumber Am), group of grant fund (Kumpulan Wang Geran), and group of special fund (Kumpulan Wang Khas). Each of these fund groups has a full set of accounts." (P4)

"each waqf has its own full set of account." (P1)

“The waqf is console in the SIRC's Fund Account except for our main special the musolla of Ahmad Dhawjee Dhadhaboy, our special waqf (waqf khas) which is a joint venture project, we as a trust holder, we provide its own full set of account and we have few committees for that special waqf and present it separately from the SIRC's financial report." (P4)

Based on table 1.1, there are SIRCs like Johor and Terengganu that provide their own manual for financial management including waqf. For instance Johor, they follow the best practice of Auditor's general and JAKIM produced in 2002 and revised their accounting treatment and develop their own manual known as Tatacara Pengurusan Kewangan. Although there are evidences that waqf institutions already adopted the PERS standard set by MASB, they still have improper accounting records regarding waqf assets. For instance, they have not properly recorded comprehensive assets listings, their current value and waqf accounts (Mustaffha et. al. 2016). The financial reports and presentation with regard to waqf are being formatted by the accountant of the SIRCs, as he is responsible for the presentation of the waqf financial statements. The researcher interprets that when the participant states the financial procedures are adapted from the best practices however it is still an optional as he can decide what would be the accounting treatments where he think appropriate

"Yes, because now we have audited financial reports, the operation needs to have an AI (Accountability Index) that every 3 years, the National Audit Department is coming. Then we have our own Internal Audit and MAIS Internal Audit. Our financial procedures are much adapted from Best Practices and where we think appropriate to be used." (P14) 
"That time I had an experience at the audit firm, I used to do this with another company, so I used my experience working in the audit firm, and apply it in this SIRCs." (P4)

\begin{tabular}{|rll|}
\hline \multicolumn{2}{|c|}{ References } & States \\
\hline 1. & SIRC Manual & Terengganu \& Johor \\
\hline 2. & Best practice of SIRC & PWS Selangor \\
\hline 3. & MPERS & $\begin{array}{l}\text { Pahang (HQ), Perak, Wilayah Persekutuan, Pulau } \\
\text { Pinang }\end{array}$ \\
\hline 4. & MFRS & $\begin{array}{l}\text { Kelantan, Pahang (unit wakaf), UME (Subsidiary of } \\
\text { PWS MAIS), Perlis }\end{array}$ \\
\hline 5. & Best Practice of JAWHAR & Kedah, Negeri Sembilan \\
\hline
\end{tabular}

Table 1.1: SIRC References

Based on the table above, all SIRCs used the references stated but after that, there will be changes and adjustments where appropriate to fit the SIRCs nature and operation. The procedure may also change from time to time due to the government circular and Board and Fatwa decision. The changes of the procedures and the issuance of government circular to the SIRCs as well as the approval and decision from the fatwa councils become the major factors of the different accounting and reporting treatment for waqf institution in Malaysia.

\section{Discussion - Divergence of Waqf Accounting and Reporting Practices}

From the analysis conducted, the diversification of the accounting and reporting for waqf is clearly stated by the examination of the waqf accounting treatments in terms of recognition, measurement and disclosure of the waqf assets. The availability of different optional guidelines and reference used by these SIRCs reflects the different treatments and reporting of waqf. These was due to the nature of the SIRCs which operate as different legal form of entity. waqf may be organised by an incorporated body of the SIRC, waqf organisation by a separate unit of the SIRC as well as waqf organisation by a department in the SIRC itself. Most of the SIRCs used the MPERs as their main guideline and, some of the SIRCs have referred to the own manual of financial managed developed by those SIRCs and one that is private company is subjected to the Malaysian Financial Reporting Standard (MFRS). Because of the optional decision to use the references and guideline available, the SIRCs' accounting and reporting treatments vary and inconsistent among each other's. The optional adoption of available guideline, may result in different treatment of waqf related activities and contribute to the diversification of waqf accounting and reporting practice among the SIRCs in Malaysia. Mohamed et al. 2006 highlight the problem of non-standardisation in preparing the financial reports and different waqf institution has its own accounting and reporting practice. Ibrahim (2001) found that different waqf councils use different valuation method. Besides, there are different approaches used by the councils in presenting their financial reports (Md. Zain \& Abdul Rahman 2006).

Besides, the central management and authority at Federal level is still minimal due to the dominant control of the SIRCs' council and Fatwa member on the financial and non-financial decision related to waqf fund of SIRCs. Any Islamic matters related must be endorsed in the Board Councils meeting and must attain the approval from the Fatwa Councils which become the main source and factor of the lack of federal central management and authority. The role of fatwa 
councils is important to most of SIRCs on certain procedures for example the capitalisation and valuation of waqf assets. Some fatwa councils do not allow the waqf assets like land and building to be valued or revalued as the waqf asset is not under SIRCs possession. The capitalisation of assets of waqf is not allowed as it contradicts with the State Enactment Act that states the role of SIRC as a trustee holder. Until now, there is conflict in term of recognition of cash waqf where some SIRCs recognised cash donated for the purpose of waqf as a liability under the Amanah Account. Whereas, there are SIRCs which recognise the cash waqf as a revenue. Thus, each states Islamic religious council has the different states fatwa committee which their fatwas decision on Islamic matters related to waqf may vary especially on matters that are not explicitly in the Quran or hadith by the Prophet but involving the discussion of fiqh. Mat Rani (2015) indicates that the Committee or State Fatwa Council shall serve the determination of fatwa by taking into account the environment and current needs, which is also known as the contemporary fatwa for example in the case of repossession of waqf land by the government which must meet the goals and interests of the public. As a result, the different shariah opinion and fatwa decision concerning waqf-related matters drive the diversification of the accounting and reporting for waqf in SIRCs in Malaysia.

To conclude this paper, although there are significant differences in waqf accounting and reporting practices are noted and the calls towards a standardised waqf accounting and reporting become rigorous, certain areas still need improvements especially on the education, qualification and the experience of waqf managers like staff training and conference to give the awareness on waqf accounting and reporting standard as well as on the importance of harmonisation of waqf accounting and reporting practice for the benefits of the Ummah as a whole. Besides, the harmonisation of waqf accounting and reporting practice may be achieved by initially considering the issues and problems faced by the waqf managers in each states in managing and administrating the waqf assets. The response and readiness of the institutional mutawwali towards a standardised waqf accounting and reporting may be useful and important aspect to be focused on in the efforts of the standard adoption realisation. Thus, further study is necessary to understand the pressures exerted in waqf institutions in Malaysia with respect to the development of accounting and reporting for waqf and the consensus of all SIRCs in Malaysia may be deemed necessary to ensure the implementation of the potential standard of waqf accounting and reporting be successful and realised.

\section{References}

Abdul Rahman, A.R. 2010. An Introduction to Islamic Accounting: Theory and Practice. Kuala Lumpur: CERT Publication.

Abdul Rahman, A.R., Bakar, M.D. \& Ismail, Y. 1999. Current practices and administration of waqf in Malaysia: a preliminary study. Awqaf Report- Malaysia.

Abdul Rahman, A.R. \& Goddard, A. 2003. Accountability: a study of accounting in State Religious Councils in Malaysia. Discussion papers in Accounting and Finance.

Adnan, Muhammad Akhyar, Maliah Sulaiman, \& Putri Nor Suad Megat Mohd Nor. 2007. Some thoughts about accounting conceptual framework and standards for awqaf institutions. Indonesian Management \& Accounting Research. 6 (1): 43-56.

Arkib. 2009, May 20. Tanah wakaf RM1.9bilion perlu dimajukan. The Utusan Online. Retrieved from http://ww1.utusan.com.my/utusan/info.asp?y=2009\&dt=0520\&pub=Utusan_Malaysia\&sec $=$ Dalam_Negeri\&pg=dn_26.htm.

Buang, A.H. 2002. Analisis fatwa-fatwa semasa Shariah di Malaysia. Jumal Syariah. 10(1): 39-52. 
Braun, V. \& Clarke, V. 2006. Using thematic analysis in psychology. Qualitative Research in Psychology. 3 (2):77-101.

Cordery, C.J., \& Morley, R.F. 2005. Hegemony, stakeholder salience and the construction of accountability in the charity sector. Paper presented at the AFAANZ Conference. Melbourne.

Dahlan, N.K., Yaa'kub, N.I., Abdul Hamid, N. \& Palil, M.K. 2014. Waqf (Endowment) Practice in Malaysian Society. International Journal of Islamic Thought. 5(June): 56-61.

Daud, D. \& Abd. Rahman, R. 2008. A preliminary study on non- financial items of waqf reporting: a preliminary survey of Johor academicians. International Accounting \& Business Conference, Puteri Pacific, Johor Bahru, Johor.

Daud, D., Abdul Rahman, R., \& Sulaiman, Z. 2011. Waqf reporting to fulfil stakeholder attribution in Waqf Islamic councils. Business management Quarterly Review (BQMR). 2(1): 38-53.

Daud, D., Abdul Rahman, R., Sulaiman, Z. and Ismail, C.Z. 2011. Waqf reporting towards transparency. International Accounting and Business Conference.

Eisenhardt, Kathleen M. 1989. Building theories from case study research academy of management. The Academy of Management Review. 14 (4): 532.

Hamdan, N., Mohd Ramli, A., Jalil, A. \& Haris, A. 2013. Accounting for waqf institutions: A review on the adaptation of fund accounting in developing the Shariah-Compliant financial reports for mosque. Presented at World Universities Islamic Philanthropy Conference 2013 (WIPCON 2013), "Transforming Islamic Philanthropy For Ummah Excellence", Organised by IKAZ and UITM, 4 \& 5 December. Menara Bank Islam.

Hasan, Z., \& Abdullah, M. N. 2008. The Investment of Waqf Land As An Instrument of Muslims' Economic Development in Malaysia. Dubai International Conference on Endowments' Investment, 4-6 February, United Arab Emirates.

Hasan, Z.A., Othman, A., Ibrahim, K., Md Shah, M.A.M. \& Mohd Noor, A.H. 2015. Management of waqf assets in Malaysia. International Journal of Nusantara Islam. 3 (1): 59-68.

Hisham, Y. 2006. Waqf accounting in Malaysian State Islamic Religious Institution: the case of federal territory SIRC. Unpublished Master's dissertation, International Islamic University Malaysia, Kuala Lumpur.

Ihsan, H. 2007. An exploratory study of waqf accounting and management in Indonesian waqf institutions: the cases of Dompet Dhuafa and UII waqf foundations (Unpublished master's thesis). International Islamic University Malaysia, Kuala Lumpur.

Ihsan, H., \& Adnan, M.A. 2009. Waqf Accounting and the construction of accountability. In: MC (IIUM Management Centre), AIKOL (Ahmad Ibrahim Kulliyyah of Laws) and IIMU (International Institute for Muslim Unity), International conference on waqf laws and management: reality and prospects. Kuala Lumpur 20-22 October 2009. Malaysia: International Islamic University.

Ihsan, H., \& Mohd Ibrahim, S. H. 2011. Waqf accounting and management in Indonesian waqf institutions: The cases of two waqf foundations. Humanomics. 27(4): 252-269.

Ihsan, H., Sulaiman, M., Mohd Alwi, N. \& Adnan, M.A. 2016. Waqf accountability from the stakeholder salience theory: A case study. Journal of Islamic Monetary Economics and Finance. 2 (1): 1-40.

Isa, Z.M., Ali, N., \& Harun, R. 2011. The Comparative Study of Waqf Management in Malaysia. International Proceedings of Economics Development \& Research. 10: 561.

Kahf, M. 1998. Financing the development of awqaf property. International Seminar on Awqaf and Economics Development, Kuala Lumpur.

Kahf, M. 1999. Towards the revival of awqaf: a few fiqhi issue to reconsider. Paper presented at the Harvard Forum on Islamic Finance and Economics. Harvard University, U.S.A. 
Masruki, R., \& Shafii, Z. 2013. The development of waqf accounting in accountability. Middle East Journal of Scientific Research 13 (Research in Contemporary Islamic Finance and Wealth Management).

Mat Rani, M.A., \& Abdul Aziz, A. 2010. Waqf management and administration in Malaysia: Its implementation from the perspective of Islamic law. Malaysian Accounting Review. 9 (2): 115-121.

Mat Rani, M.A. 2015. Fatwa on waqf: Specialized analysis in hand over of waqf lands by state authority. International Journal of Nusantara Islam. 3 (1): 47-58.

Md. Zain and Abdul Rahman. 2006. Determination of financial reporting practices o waqf by Malaysian State Islamic Religious Councils. IIUM International Accounting Conference III, 2628 June. Kuala Lumpur.

Miles, M. B., and A. M. Huberman. 1994. Qualitative Data Analysis: An Expanded Sourcebook. 2nd ed. Thousand Oaks: Sage Publications.

Miles, M. B., Huberman, A. M. \& Saldaña, J. 2014. Qualitative Data Analysis: A Methods Sourcebook (3rd ed.). Thousand Oaks, CA: Sage.

Mohamad, N.A, Syed Abdul Kader, S.Z. \& Ali, Z. 2012. Waqf lands and challenges from the legal perspectives in Malaysia. IIUM-Tokyo Joint Symposium

Mohamad Zaim, I., Muhammad Ikhlas, R., \& Mohd Anuar, R. 2015. Pemerkasaan Wakaf di Malaysia. Labuan e-Journal of Muamalat and Society. 9: 1-13.

Mohamed, S., Daud, D., Md. Zain, S.R. \& Yaccob, C.A. 2006. Kearah Pelaksanaan Sistem Perakaunan Wakaf Yang Piawai. Konvekesyen Wakaf Kebangsaan, anjuran Jabatan Wakaf, Zakat dan Haji, Jabatan Perdana Menteri, Putrajaya.

Mohd Nasir, N., Othman, R., Said, J. \& Ghani, E. 2009. Financial reporting practices of charity organisations: A Malaysian evidence. International Bulletin of Business Administration. 6: 1927.

Mohd Saharudin Shakrani, Jaafar Ahmad \& Mohd Saifoul Zamzuri Noor. 2003. Tinjauan Awal Isu-Isu yang Membataskan Penggunaan Wakaf dalam Pembangunan Ekonomi Ummah di Malaysia. Presented at Bengkel Ekonomi Islam, UKM 15 January.

Mustafa, S. S. 2007. Pengurusan dan Pembangunan Hartanah Wakaf: Kajian di Terengganu. (Unpublished master's thesis). Faculty of Islamic Studies, International Islamic University Malaysia.

Mustaffha, N., \& Zainal, M. F. 2016. Waqf and accounting treatment: Pursuing the transparency and accountability - A case study. Proceeding of the 3 rd International Conference on Masjid, Zakat and Waqf (IMAF 2016) (e-ISBN 978-967-13087-2-1). 1 December 2016, Shah Alam, Selangor, MALAYSIA.

Nasution, K.S. 2002. Colonial intervention and transformation of Muslim Waqf Settlements in urban Penang: The role of the Endowments Board. Journal of Muslim Minority Affairs. 22(2): 299315.

Sayin, B., Ali, A. \& Suyurno, S. 2006. Kajian Perbandingan Pengurusan Wakaf Di Malaysia: Kajian Kes Di Johor, Melaka, Perak, Pulau Pinang, Sabah, Sarawak, Selangor, Terengganu dan Perbadanan Wakaf Malaysia. UITM.

Syed Abdul Kadir, S.Z. and Mohd Dahlan, N.H. 2011. Current legal issues concerning awqaf in Malaysia.Waqf Law and Management: Reality and Prospect. Abdul Haseeb Ansari (ed.). Kuala Lumpur: IIUM Press.

Siti Rokyah, M.Z. 2005. Determinants of financial reporting practices on waqf by Malaysian state Islamic religious Council in Malaysia (Unpublished Master's thesis). International Islamic University Malaysia, Kuala Lumpur, Malaysia. 
Strauss, A. \& Corbin, J. 2008. Basic of Qualitative Research: Technique and Procedures for Developing Grounded Theory. London: Sage Publication.

Weitzman, E. A. 2000. Software and Qualitative Research. In Handbook of Qualitative Research, by Norman K. Denzin and Yvonna S. Lincoln, 803-820. Thousand Oaks: Sage Publications.

Yaacob, H. 2013. Waqf history and legislation in Malaysia: A contemporary perspective. Journal of Islamic and Human Advanced Research. 3 (6): 387-402.

Yin, R.K. 1994. Case Study Research: Design and Methods. $2^{\text {nd }}$ ed. Thousand Oaks, CA: Sage Publishing.

Yin, R.K. 2015. Qualitative Research from Start to Finish. $2^{\text {nd }}$ ed. New York: The Guilford Press. 